\title{
Volcanism and associated hazards: the Andean perspective
}

\author{
R. I. Tilling \\ Scientist Emeritus, Volcano Hazards Team, US Geological Survey, Menlo Park, California 94025-3591, USA
}

Received: 30 June 2009 - Revised: 8 August 2009 - Accepted: 9 August - Published: 14 December 2009

\begin{abstract}
Andean volcanism occurs within the Andean Volcanic Arc (AVA), which is the product of subduction of the Nazca Plate and Antarctica Plates beneath the South America Plate. The AVA is Earth's longest but discontinuous continental-margin volcanic arc, which consists of four distinct segments: Northern Volcanic Zone, Central Volcanic Zone, Southern Volcanic Zone, and Austral Volcanic Zone. These segments are separated by volcanically inactive gaps that are inferred to indicate regions where the dips of the subducting plates are too shallow to favor the magma generation needed to sustain volcanism. The Andes host more volcanoes that have been active during the Holocene (past 10000 years) than any other volcanic region in the world, as well as giant caldera systems that have produced 6 of the 47 largest explosive eruptions (so-called "super eruptions") recognized worldwide that have occurred from the Ordovician to the Pleistocene.

The Andean region's most powerful historical explosive eruption occurred in 1600 at Huaynaputina Volcano (Peru). The impacts of this event, whose eruptive volume exceeded $11 \mathrm{~km}^{3}$, were widespread, with distal ashfall reported at distances $>1000 \mathrm{~km}$ away. Despite the huge size of the Huaynaputina eruption, human fatalities from hazardous processes (pyroclastic flows, ashfalls, volcanogenic earthquakes, and lahars) were comparatively small owing to the low population density at the time. In contrast, lahars generated by a much smaller eruption $\left(<0.05 \mathrm{~km}^{3}\right)$ in 1985 of Nevado del Ruiz (Colombia) killed about 25000 people - the worst volcanic disaster in the Andean region as well as the second worst in the world in the 20th century. The Ruiz tragedy has been attributed largely to ineffective communications of hazards information and indecisiveness by government officials, rather than any major deficiencies in scientific data. Ruiz's
\end{abstract}

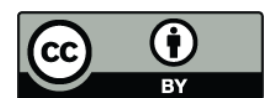

Correspondence to: R. I. Tilling (volkno@earthlink.net) disastrous outcome, however, together with responses to subsequent hazardous eruptions in Chile, Colombia, Ecuador, and Peru has spurred significant improvements in reducing volcano risk in the Andean region. But much remains to be done.

\section{Introduction}

The Andes (Cordillera de Los Andes) - sometimes called the tectonic "backbone" of the South America (Fig. 1) - comprise one of Earth's highest subaerial mountain ranges. The Andean region also has been the principal locus of magmatism and volcanism in the South American continent since the Late Triassic (e.g., Scheuber and Reutter, 1992; Gelcich et al., 2005; Oliveros et al., 2006). A number of the volcanoes of the present-day Andean Volcanic Arc have erupted one or more times in recorded history (i.e., since the arrival of Spaniards in the 15th century). In the coming decades, with continuing population growth and expanding economic development of the Andean countries, the risk posed by volcanic hazards from future eruptions will inexorably increase.

This brief paper is adapted from a keynote address presented at the Fourth Alexander von Humboldt Conference in Santiago, Chile, in November 2008 (Tilling, 2008b). This conference was primarily focused on the themes of glaciology, climate change, and geodynamics. My presentation was aimed to provide a broad-brush overview of Andean volcanism and associated hazards - against a global and historical background - in a manner readily understandable to the many non-volcanologists among the conference participants. For more detailed information about any specific aspect of this paper, the interested reader is referred to the many original papers cited herein. A good starting point is the excellent review paper by Stern (2004), which is the most comprehensive summary to date of active Andean volcanism. 


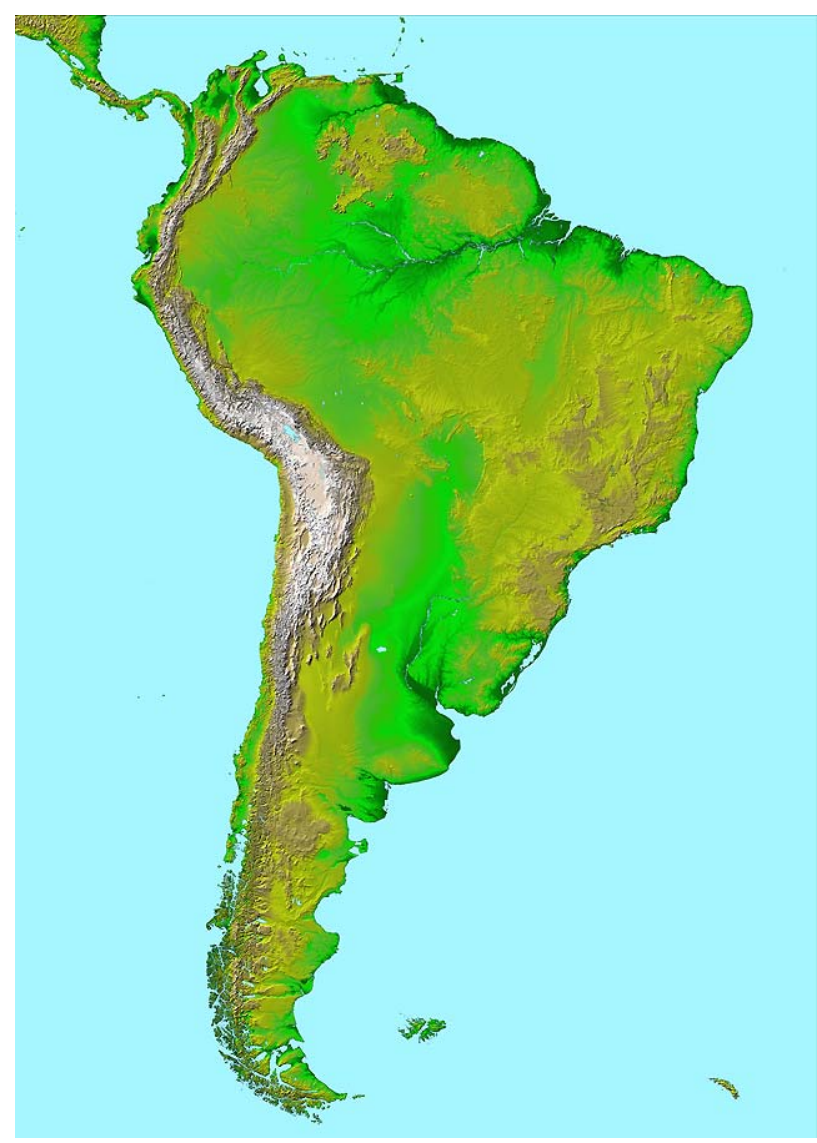

Fig. 1. The prominent mountainous belt making up the Andean chain (Cordillera de Los Andes) stretches approximately $8000 \mathrm{~km}$ north to south from Venezuela to Patagonian Chile along the western margin of South American continent. The Andes - the "backbone" of South America - are clearly seen in this Radar Shuttle Topography image. (SRTM NASA/JPL, http://photojournal.jpl.nasa. gov/tiff/PIAO3388.tif).

\section{Andean Volcanic Arc (AVA)}

The Andean range has formed by the subduction of the Nazca and Antarctica Plates beneath the South America Plate since at least the late Paleozoic (Fig. 2). Plate-tectonics processes have also developed and sustained the Andean Volcanic Arc (AVA), which contains numerous volcanoes, including Earth's highest volcano, Nevados Ojos del Salado (Chile), whose summit is $6887 \mathrm{~m}$ a.s.l. Moreover, the AVA hosts more large composite volcanoes (122) that have erupted during the Holocene than any other volcanic region (Simkin and Siebert, 1994); many of these topographically high, steep-sided volcanoes have summits capped by ice and snow. At such volcanoes, there exists great potential for the generation of far-travelling destructive lahars (volcanic mudflows) during and following eruptions, thereby making them exceptionally hazardous. For example, during the 1877 eruption of Cotopaxi Volcano (Ecuador), devastating lahars swept

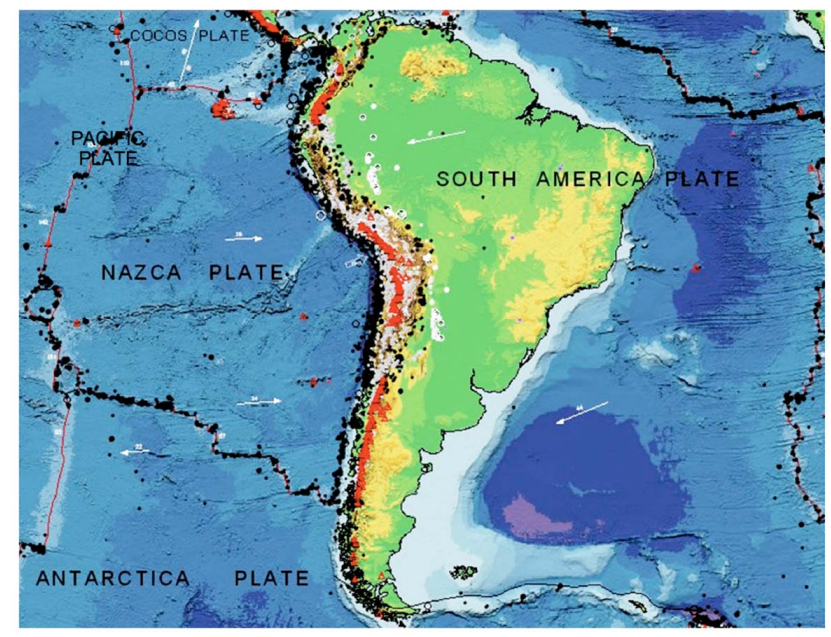

Fig. 2. The Andean Volcanic Arc (AVA) has formed by the subduction of the Nazca and Antarctica Plates beneath the South America Plate. The present-day AVA is well expressed by the string of Andean volcanoes that have been active since the Holocene, as delineated by the solid and open red triangles on this portion of the world plate tectonics map of Simkin et al. (2006). The circles (black, white, and open) mark earthquakes of magnitude 5 or greater; the segmented red lines show divergent plate boundaries.

down valleys draining the volcano; the largest lahars traveled $>300 \mathrm{~km}$ to reach the Pacific Ocean (Mothes et al., 2004; Kumagai et al., 2007; Hall and Mothes, 2008).

It is beyond the scope of this paper to discuss the AVA in detail. For a helpful introduction to Andean magmatism and associated volcanism, the interested reader should consult available summary works and references cited therein (e.g., Barberi et al., 1988; Méndez Fajury, 1989; De Silva and Francis, 1991; González-Ferrán, 1995; Stern, 2004; Hall et al., 2008). The following two websites also provide useful information about Holocene volcanoes in South America:

- http://www.volcano.si.edu/world/region.cfm?rnum= $15\{\backslash \&\}$ rpage=list $>$; and

- http://mineralsciences.si.edu/tdpmap.

As discussed in the sections to follow, dozens of Andean volcanoes have erupted powerfully in the geologic past as well as during historical time.

The AVA is Earth's longest continental-margin volcanic $\operatorname{arc}(>8000 \mathrm{~km}$ long), but it is not continuous along its length. Instead, it consists of four distinct segments (Fig. 3): the Northern Volcanic Zone (NVZ), along Colombia and Ecuador; the Central Volcanic Zone (CVZ), extending from southern Peru to northern Chile; the Southern Volcanic Zone (SVZ), encompassing central and southern Chile; and the Austral Volcanic Zone (AVZ), stretching from the Chile Triple Junction to the Patagonian archipelago. The various zones of the AVA are separated by volcanically inactive gaps 


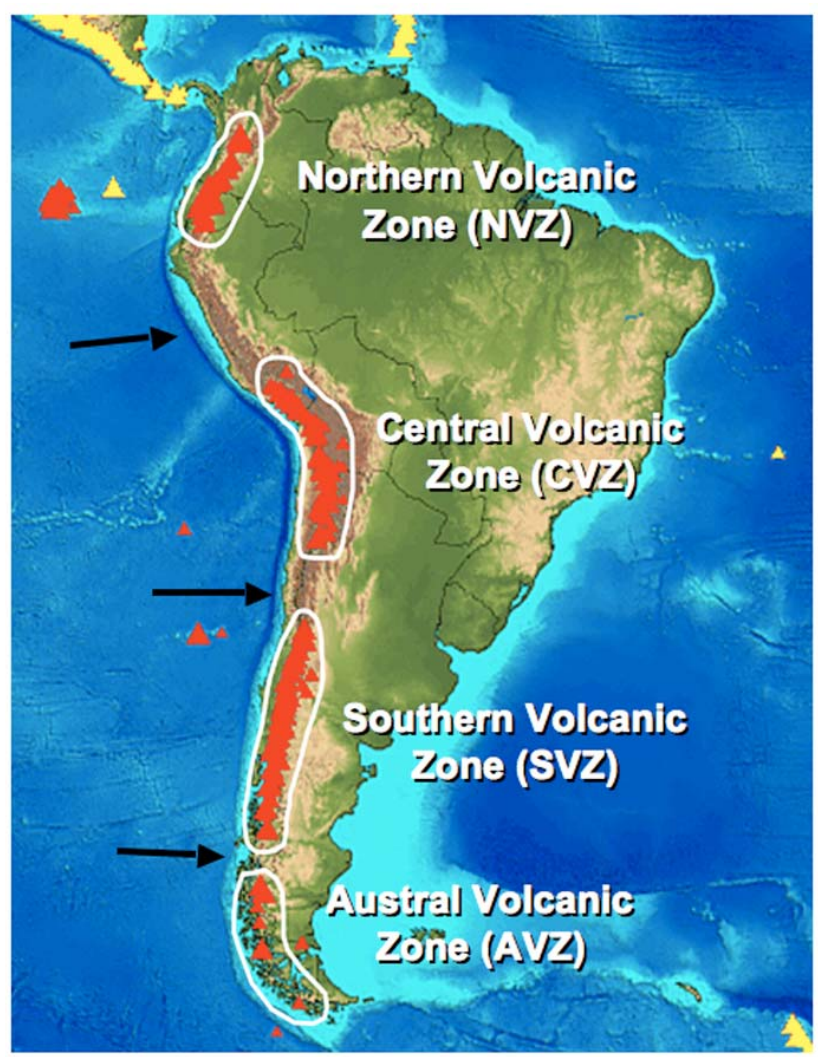

Fig. 3. The Andean Volcanic Arc is not continuous and consists of four segments, which are separated by volcanically inactive gaps hundreds of kilometers in length (see text). The black arrows mark regions where the subduction angle is relatively flat.

hundreds of kilometers in length. There is no general agreement about the reason(s) for the segmentation of the Andean volcanic arc. However, a commonly invoked hypothesis (e.g., Stern, 2004) is that these gaps coincide with regions where the dips of the subducting plates are too shallow $\left(\sim 10^{\circ}\right.$ or less at depths $>100 \mathrm{~km}$ ) to favor generation of magma by partial melting in hot mantle that sustains volcanism.

\section{Andean eruptions over geologic time}

\subsection{The Volcanic Explosivity Index (VEI)}

Before discussing eruptions in the Andean region, to provide global and historical context, it is useful to review briefly the Volcanic Explosivity Index (VEI) devised by Newhall and Self (1982). This semi-quantitative, logarithmic VEI scale has become the tool most widely used by volcanologists to estimate the relative size or magnitude of an explosive eruption. The open-ended VEI scale applies only to explosive eruptions, with the VEI value determined primarily by the volume of eruptive products, height of the eruption cloud, and eruption duration, but with qualitative obser-

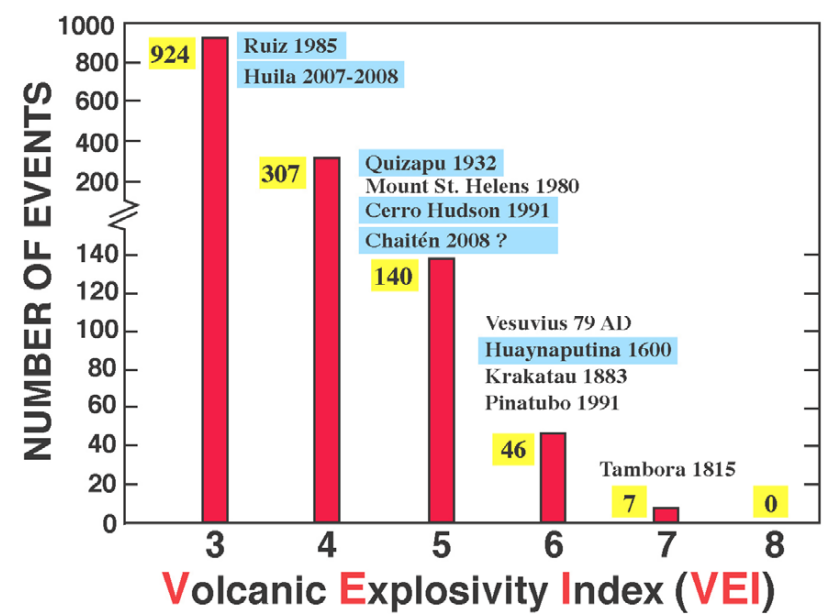

Fig. 4. Histogram of Holocene eruptions for which VEIs (see text for discussion) have been assigned; note the break in scale in the vertical axis. The number of eruptions with assigned VEIs $\leq 2$ (total of 5349 events) is not plotted because of scale limitation. Numbers highlighted in yellow give the number of eruptions of in each VEI ranking, as compiled in the Volcano Database of the Smithsonian Institution (Simkin and Siebert, 1994). A few selected historical eruptions mentioned in this paper are given to provide illustrative examples (Andean eruptions highlighted in blue).

vations of explosivity (e.g., "gentle," "cataclysmic," "colossal") also considered. A non-explosive eruption is assigned a VEI of 0 regardless of size, and an increase of 1 in the VEI corresponds to an eruption roughly 10 times more "powerful." In general, the longer the repose interval between eruptions, the more explosive (i.e., resulting in a higher VEI) is the next eruption (Simkin and Siebert, 1994). Figure 4 is a summary of explosive eruptions in the world during the Holocene ranked by VEI; note that no Holocene eruption is ranked higher than VEI 7. The 1815 eruption of Tambora Volcano (Indonesia) - the largest in the world in recorded history - is the only historical volcanic event to be assigned VEI 7 (Fig. 4).

\subsection{Pre-Holocene Andean "super eruptions"}

To furnish context for Andean volcanism, geologic data worldwide indicate that prehistoric eruptions can be much, much larger than the largest eruption (Tambora, 1815) humankind has experienced in historical time. The largest of the prehistoric eruptions ( $>$ VEI 7 ) are all pre-Holocene - fortunately having occurred before the dawn of civilization. In a comprehensive compilation of the largest explosive eruptions in the past $\sim 490$ million years (Ordovician - Pleistocene), Mason et al. (2004) recognized 47 so-called "super eruptions" worldwide, 42 of which occurred during the past 36 million years. These authors define a "super eruption" as one having VEI $>7$ or a "magnitude" equal to 8 or greater $(\geq \mathrm{M}-8)$. Their "magnitude" scale of eruption size, based on 
Table 1. Quaternary Andean "super eruptions" from caldera/ignimbrite systems in the Altiplano-Puna plateau of the central Andes. A "super eruption" is defined by Mason et al. (2004) as one erupting $\geq 10^{15} \mathrm{~kg}$ of ejecta; $\mathrm{Ma}=$ millions of years ago. (Data source: Mason et al., 2004, Table 2).

\begin{tabular}{lll}
\hline Caldera & $\begin{array}{l}\text { Eruptive deposit(s) } \\
\text { (ignimbrites) }\end{array}$ & $\begin{array}{l}\text { Geologic } \\
\text { age (Ma) }\end{array}$ \\
\hline Cerro Galan, Argentina & Cerro Galan & 2.2 \\
La Pacana, Chile & Atana & $\sim 4$ \\
Cerro Galan, Argentina & Real Grande, Cueva Negra & 4.2 \\
Unknown, central Andes & Huaysillas & 5 \\
Cerro Panizos, central Andes & Panizos & 6.1 \\
Pastos Grandes, central Andes & Sifon & 8.3 \\
\hline
\end{tabular}

eruptive mass, is proportionately comparable to the VEI scale (based on eruptive volume) but differs by taking into account the estimated bulk density of eruptive deposits. As defined by Mason et al. (2004), a M-8 eruption has an eruptive mass of $>10^{15} \mathrm{~kg}$, or about 150 times more than was erupted during the 1991 eruption of Mount Pinatubo (Newhall and Punongbayan, 1996), the second largest in the world in the 20th century.

About a dozen giant caldera/ignimbrite systems are located within the Altiplano-Puna plateau of the central Andes (Allmendinger et al., 1997; Stern, 2004). Of the "super eruptions" recognized worldwide, 6 of them have occurred within the central Andes during the period between 9 and 2 million years (Table 1). Thus, the Andean region has had its fair share of Earth's "super eruptions" in the geologic past. Although it's unlikely that super eruptions have stopped in the Andean or any other volcanic region, fortunately they are infrequent, and the odds of another in the near (foreseeable?) future are small. Yet, it should be mentioned that volcanic unrest - involving seismicity and ground deformation - has been documented for some caldera systems in the world (e.g., Newhall and Dzurisin, 1988; Waite and Smith, 2002; Hill, 2006; Wicks et al., 2006; Troise et al., 2007). As an Andean example, caldera-scale ground deformation (involving an area $\sim 1100 \mathrm{~km}^{2}$ ) at the Lazufre volcanic center, documented by Interferometric Synthethic Radar (InSAR) studies, has been inferred to represent inflation of a subsurface magma reservoir (Froger et al., 2007; Ruch et al., 2008).

\subsection{Holocene and historical Andean volcanism}

The Andes host 204 of the approximately 1500 volcanoes active during the Holocene (past 10000 years) worldwide - more than any other volcanic region (Simkin and Siebert, 1994). According to the global volcano database of the Smithsonian Institution as compiled by Simkin and Siebert (1994), Andean volcanoes have produced about 18 percent of the $\sim 500$ Holocene eruptions that are ranked VEI 4 or greater (Fig. 4). The Andean region contains 66 of
Table 2. Largest explosive eruptions in the Andean region during the 19th-21st centuries, with assigned Volcanic Explosivity Index (VEI) equal to or greater than 4 (see text for discussion). Data sources: Simkin and Siebert (1994); GVPc (2009).

\begin{tabular}{clr}
\hline Year & Eruption & VEI \\
\hline 1877 & Cotopaxi, Ecuador & 4 \\
1886 & Tungurahua, Ecuador & 4 \\
1893 & Calbuco, Chile & 4 \\
1899 & Dona Juana, Colombia & 4 \\
1918 & Tungurahua, Ecuador & 4 \\
1932 & Quizapu (Cerro Azul), Chile & $5+$ \\
1955 & Carran-Los Venados, Chile & 4 \\
1991 & Cerro Hudson, Chile & $5+$ \\
1993 & Lascar, Chile & 4 \\
2002 & Reventador, Ecuador & 4 \\
2008 & Chaitén, Chile & $5 ?$ \\
\hline
\end{tabular}

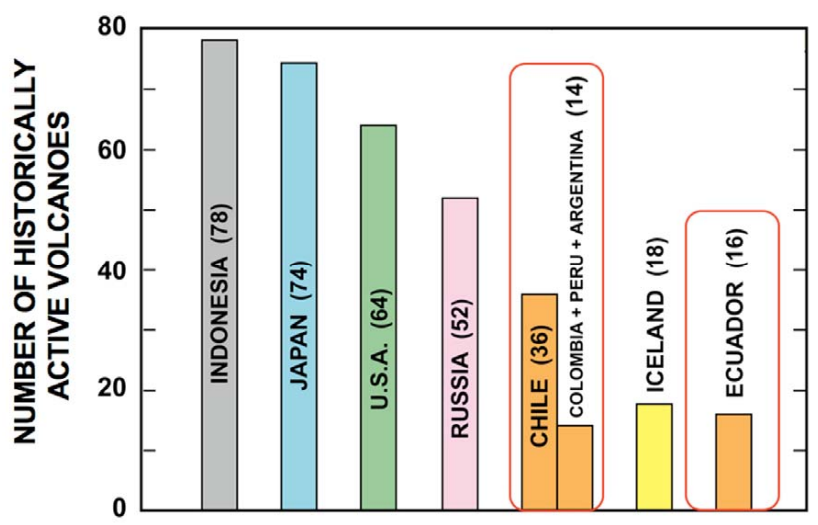

Fig. 5. Histogram of historically active volcanoes grouped by country; the numbers in parentheses indicate the number of individual volcanoes. The Andean countries combined (highlighted by red outlines) host 66 of the $\sim 550$ historically active volcanoes worldwide (primary data source: Simkin and Siebert, 1994).

the world's $\sim 550$ historically active volcanoes, ranking third (after Indonesia and Japan) in having the most volcanoes that have erupted one or more times in recorded history (Fig. 5). Since the year 1800, Andean volcanoes have produced 11 documented explosive eruptions (6 in Chile) ranked VEI 4 or higher (Table 2) - the same number as that for Japan, which has more historically active volcanoes (Fig. 5). However, Chile and neighboring Argentina, which is downwind and receives most of the ashfalls, have much lower population densities than that of Japan. Because of this fortunate circumstance, large explosive eruptions in the Andes during the past 200 years have caused much less severe eruptionrelated impacts. 


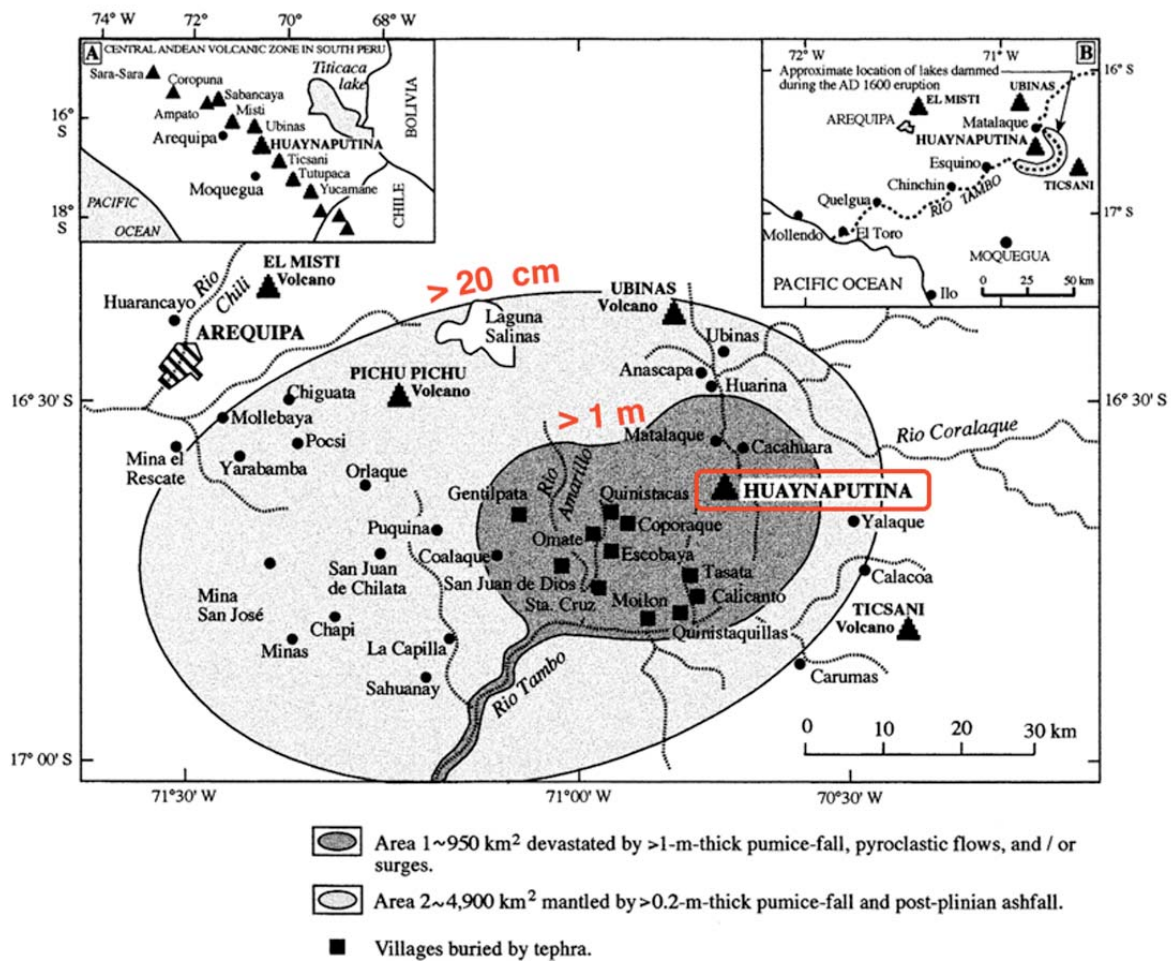

Fig. 6. Sketch map showing the regional ashfall from the 1600 AD eruption of Huaynaputina Volcano (southern Peru), Central Volcanic Zone of the Andean Volcanic Arc. The area within the $1 \mathrm{~m}$ isopach (dark grey) was devastated by pyroclastic flows and surges and heavy ashfall; the solid black squares indicate villages buried by ash (from Thouret et al., 2002, Fig. 1).

\subsection{Some powerful historical Andean eruptions}

The Andean region's most powerful historical explosive eruption occurred on 19 February 1600 at Huaynaputina Volcano, Peru. This eruption is the only one in the Andes assigned a VEI of 6 (Fig. 4). Even though the population in the affected region was relatively small at the time, the impacts of such a large eruption were still extremely destructive. An extensive area $\left(\sim 950 \mathrm{~km}^{2}\right)$ immediately to the west of Huaynaputina was devastated by pyroclastic flows and surges and heavy ashfalls (Fig. 6). The city of Arequipa, $\sim 75 \mathrm{~km} \mathrm{NW}$ of the volcano, was severely damaged by eruption-associated earthquakes and ashfalls. Distal ashfalls were reported at Lima, Peru, La Paz, Bolivia, and Arica, Chile, as well as on a ship $1000 \mathrm{~km}$ to the west of the Pacific coast. Eruptiontriggered lahars traveled more than $100 \mathrm{~km}$ to enter the Pacific Ocean (De Silva and Zielinski, 1998; Adams et al., 2001; Thouret et al., 1999, 2002). In all, more than 1500 people were killed by the pyroclastic flows, ashfalls, earthquakes, and lahars. While controversial, some studies (e.g., De Silva and Zielinski, 1998; Verosub and Lippmann, 2008; Briffa et al., 1998) suggest that the eruption also may have affected global climate, with the winter of 1600-1601 being the coldest in the Northern Hemisphere in the past 500 years. Now in the 21st century, with greatly increased populations of the Andean countries, the occurrence a Huaynaputina- size eruption would cause many more fatalities, major socioeconomic loss, and hardships for people in the Andean region.

Following the 1600 Huaynaputina eruption, the two next largest Andean eruptions took place in Chile: Quizapu (Cerro Azul) in 1932 and Cerro Hudson in 1991. The Quizapu eruption, which ejected $\sim 9.5 \mathrm{~km}^{3}$ of material (Hildreth and Drake, 1992), was the largest eruption of any Andean volcano in the 20th century. This eruption produced heavy ashfalls that drifted downwind to the east (Fig. 7); distal ashfall was even reported in Rio Janeiro, Brazil (González-Ferrán, 1995). Even though the volcano is located in a remote part of Chile and ashfalls mostly affected sparsely populated parts of neighboring Argentina (Fig. 7), ashfalls locally killed livestock and caused moderate to severe damage to agricultural lands. Significantly, the Quizapu eruption, though very powerful, produced no eruption-related human fatalities.

The 1991 Cerro Hudson eruption, the second largest in the Andes in the 20th century, was somewhat smaller in eruptive volume $\left(\sim 8 \mathrm{~km}^{3}\right)$ than that for Quizapu. It too caused heavy ashfalls to the southeast (Fig. 8), and distal ashfall reached the Falkland Islands. This eruption was relatively rich in sulfur dioxide gas for an Andean volcano (see TOMS-VEG, 2008), locally killing livestock and causing severe damage to property and agriculture (Bitschene, 1995). Table $3 \mathrm{com}$ - 


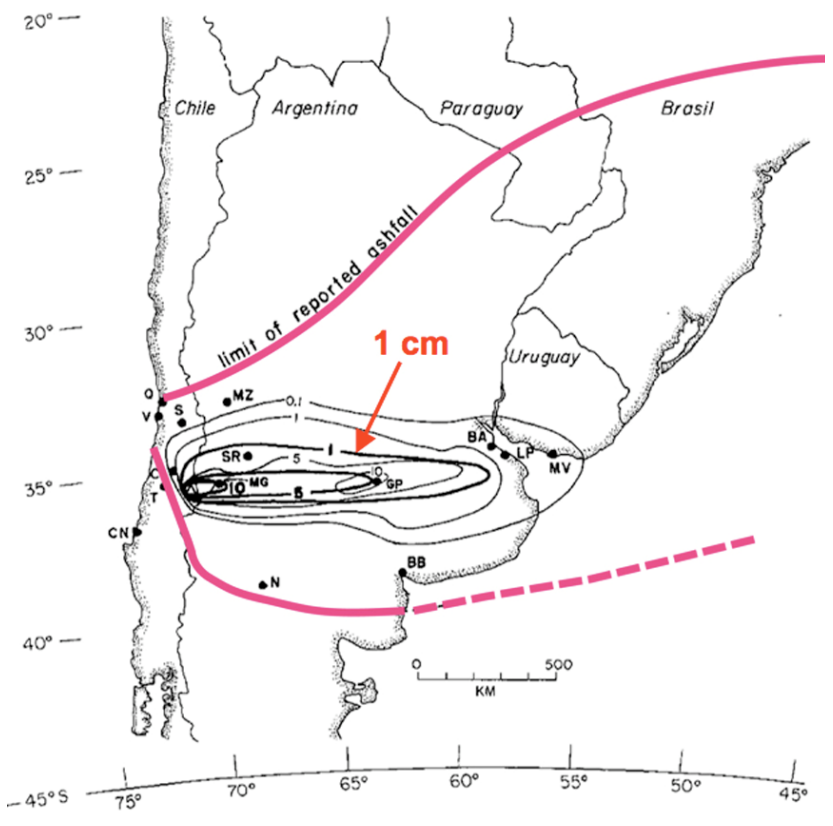

Fig. 7. Isopach map of the ashfall from the 1932 Quizapu (Cerro Azul) eruption, Chile. The thin-line isopachs are for uncompacted ash (from Larsson, 1937), and the heavy-line isopachs are those measured by Hildreth and Drake (1992) during 1980-1991. The limit of reported ashfall is indicated by heavy red line, and the $1 \mathrm{~cm}$ isopach by the red arrow (from Hildreth and Drake, 1992, Fig. 1).

pares the 1600 Huaynaputina eruption with the largest explosive eruptions of the 19th and 20th centuries worldwide; note that 3 of the 7 largest historical eruptions occurred in the Andean Volcanic Arc.

\section{Volcano hazards and disasters}

Eruptive processes and products associated with arc volcanoes, such as those in the Andes, can pose significant hazards if they impact populated regions, agricultural areas, transportation and utility networks, and other societal infrastructures. Inasmuch as the literature on volcano hazards, volcano monitoring, and reduction of volcano risk is vast, this brief paper only will mention selected aspects germane to recent Andean eruptions. For a comprehensive introduction to volcano hazards and monitoring studies, the interested reader should consult summary works and references cited therein (e.g., Blong, 1984; Tilling, 1989, 2005; Scarpa and Tilling, 1996; Chouet, 2004; Dzurisin, 2006).

Globally, Indonesia has suffered the most eruption-related deaths $(\sim 61 \%)$ from historical eruptions (Fig. 9). This observation is not surprising given that Indonesia has the most historically active volcanoes (Fig. 5) and the country's high population density, especially the Island of Java. Yet, even though South America has fewer historically active volcanoes than Indonesia, much smaller population, and lower
Table 3. The 1600 Huaynaputina eruption compared with the largest explosive eruptions of the 19th and 20th centuries worldwide. VEI=Volcanic Explosivity Index; ${ }^{*}$ Andean eruption. Note the wide range of estimated bulk volumes for the Huaynaputina and Tambora eruptions. (Various data sources, including: Naranjo et al., 1993; Simkin and Siebert, 1994; De Silva and Zielinksi, 1998; Hildreth and Drake, 1992; Thouret et al., 2002; Mason et al., 2004).

\begin{tabular}{llrr}
\hline Year & Eruption & VEI & $\begin{array}{r}\text { Bulk volume } \\
\left(\mathrm{km}^{3}\right)\end{array}$ \\
\hline 1600 & Huaynaputina, Peru * & 6 & $11-19$ \\
1815 & Tambora, Indonesia & 7 & $30-150$ \\
1883 & Krakatau, Indonesia & 6 & $\sim 18$ \\
1912 & Novarupta, USA & 6 & $\sim 15$ \\
1932 & Quizapu (Cerro Azul) * Chile & $5+$ & $>9$ \\
1991 & Mount Pinatubo, Philippines & 6 & $\sim 10$ \\
1991 & Cerro Hudson, Chile * & $5+$ & $\sim 8$ \\
\hline
\end{tabular}

population density, it ranks third $(\sim 9.5 \%)$ in terms of eruption fatalities (Fig. 9). This apparent anomaly is readily explained by the disastrous outcome of a single Andean eruption in 1985 at Nevado del Ruiz, Colombia (discussed below).

\subsection{Recent notable eruptions}

Nevado del Ruiz, Colombia, 1985. Following nearly a year of volcano unrest, which was being monitored by an international scientific team, the $5321 \mathrm{~m}$-high, glacier-capped Ruiz Volcano erupted explosively on 13 November 1985 (Williams, 1990a, b; Voight, 1994). Its bulk eruptive volume $\left(<0.05 \mathrm{~km}^{3}\right)$ was orders of magnitude smaller than those of many other historical Andean eruptions. Nonetheless, hot pyroclastic ejecta melted the ice and snow around the volcano's summit, and the resulting meltwater mixed with the volcanic and other unconsolidated debris to generate lahars. These lahars then swept rapidly down several steep valleys draining the volcano, scouring and entraining material eroded en route ("bulking up"), before inundating the populated and cultivated areas down valley. Deadly lahars obliterated everything in their paths and killed about 25000 people, nearly 23000 in the city of Armero alone (Fig. 10). The disproportionately high death toll from the 1985 Ruiz eruption (VEI 3?) can be appreciated by comparing it with fatalities caused by other deadly historical eruptions worldwide, all of which were much larger in size (Fig. 11).

The 1985 Ruiz eruption and its tragic outcome resulted in the worst volcanic disaster in the recorded history of South America. Indeed, the Ruiz tragedy represents the deadliest volcanic disaster in the world since the 1902 eruption of Mont Pelée (Martinique) in the Caribbean, which killed $\sim 30000$ people by pyroclastic flows and surges. The small, but lethal, Ruiz eruption and its disastrous aftermath 


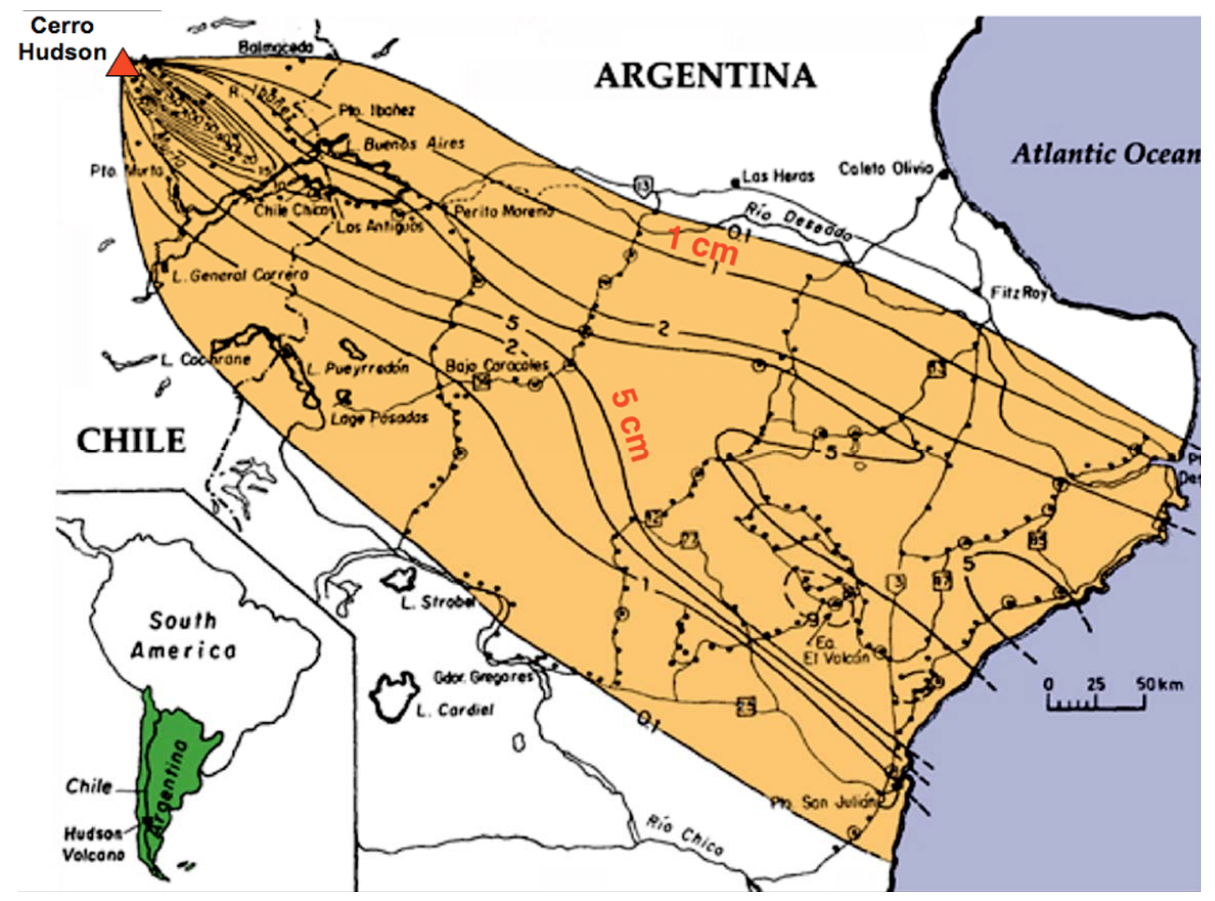

Fig. 8. Isopach map of the ashfall from the 1991 Cerro Hudson eruption, Chile. The $1 \mathrm{~cm}$ and $5 \mathrm{~cm}$ isopachs are indicated by red labels (from Scasso et al., 1994, Fig. 1).

have been documented in numerous post-1985 studies (e.g., Williams, 1990a, b; Voight, 1994). With minor differences in emphasis, these studies all basically conclude that the Ruiz tragedy happened because of: 1) ineffective communications among scientists, civil authorities, and the populations at risk; and 2) emergency-management officials failed to act in a timely fashion, despite having advance, though imperfect warnings given by scientists. The conclusion of Voight (1996, p. 719) aptly conveys what went wrong at Ruiz:

"Scientific studies foresaw the hazards - including the recognition that several towns were in the "wrong place," vulnerable to lahars generated by eruption-induced snowmelt - but were insufficiently precise to prompt reliable warning of the crucial event before the last possible minute. The catastrophe was not caused by technological ineffectiveness or defectiveness, nor by an overwhelming eruption or an improbable run of bad luck, but rather by cumulative human error." (italics added).

The Ruiz tragedy shocked the world and spurred the government of Colombia to greatly augment the monitoring of its hazardous volcanoes. Since 1985, the country has established three modern volcano observatories - located in Manizales, Pasto, and Popayán - operated by the Instituto Colombiano de Geología y Minería (INGEOMINAS). Moreover, in the decades following the disastrous outcome of the Ruiz eruption, as well as the occurrence of subsequent volcanic crises, also prompted the establishment or the modernization of volcano observatories in Chile (Observatorio Volcanológico de los Andes del Sur), Ecuador (Instituto
Geofísico-Escuela Politécnica Nacional), and Peru (Instituto Geofísico del Perú and the Observatorio Volcanlógica de Arequipa). The 1985 Ruiz disaster served to energize the global volcanological community, and the response in the U.S. was to develop the Volcano Disaster Assistance Program (VDAP), discussed later (see Sect. 6).

Nevado del Huila, Colombia, 2007-present. Ice-capped Nevado del Huila, located approximately $200 \mathrm{~km}$ to the south of Nevado del Ruiz, is the highest active volcano in Colombia (summit $5364 \mathrm{~m}$ a.s.1.). Quiescent since the mid-16th century, this volcano began to erupted explosively in February and again in April 2007, and activity has continued intermittently, but more weakly, to the present (GVPa, 2009). Like the 1985 Ruiz eruption, the 2007 Huila eruptions (VEI 23 ?) also produced destructive lahars, some of which traveled more $120 \mathrm{~km}$ down the valley of Río Paez. However, because the volcano had been monitored seismically since 1993, INGEOMINAS scientists, assisted by a USGS-VDAP team, seismic precursors of the eruption were recognized in time (Cardona et al., 2007; Pulgarin et al., 2007) to forecast lahars and to alert local emergency-management authorities who ordered timely evacuations of about 5000 people. Consequently, even though the lahars destroyed houses, killed livestock, and damaged cultivated areas, no serious injuries were incurred and no human lives were lost (Calvache, 2007; Agudelo and Calvache, 2007). The successful INGEOMINAS/VDAP responses to the 2007 Huila eruptions mark a complete reversal of the disastrous outcome of the 1985 Ruiz eruption $\sim 20$ years earlier, even though these eruptions were 


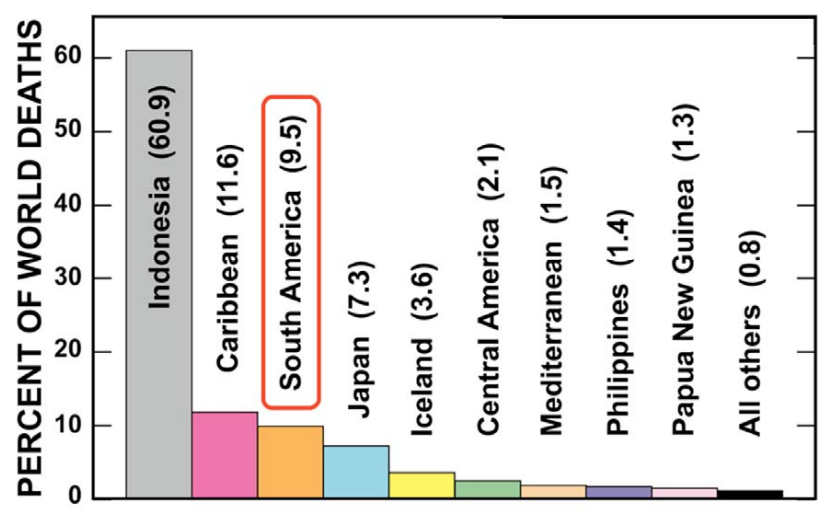

Fig. 9. Histogram of eruption-related deaths worldwide ( 300000$)$ since $1600 \mathrm{AD}$ grouped according to country or volcanic region. Numbers in parentheses give the percentages of worldwide deaths for each region. South America ranks third in eruption fatalities, which overwhelmingly reflect a single event, the Ruiz volcanic disaster in 1985 (see text) (primary data source: Simkin and Siebert, 1994).

of comparable size and both involved lahar hazards. The 2007 Nevado del Huila case history is an illustrative example of the substantial progress being made in the Andean countries in responding to volcanic crises.

Volcán Chaitén, Chile, 2008-present. On 2 May 2008, Chaitén Volcano erupted explosively after less than $36 \mathrm{~h}$ of precursory seismicity (recorded by instruments $\sim 300 \mathrm{~km}$ distant) and produced an ash plume that rose $21 \mathrm{~km}$ into the atmosphere (Lara, 2009; Carn et al., 2009). This event marks the first historical eruption of Chaitén; its previous eruption occurred about 9400 years ago (Naranjo and Stern, 2004). Scientists of Chile's Servicio Nacional de Geología y Minería (SERNAGEOMIN) immediately worked with regional and national government authorities to assess the potential hazards and volcanic crisis (Lara, 2009; Moreno and Lara, 2008). During 4-5 May, emergency-management officials ordered the immediate evacuation of about 5000 inhabitants at risk (Lara, 2009). This timely and quickly executed action doubtless saved many lives, given that the city of Chaitén was devastated by lahars and floods shortly thereafter, on 12 May (Fig. 12a).

Between 2 May and 8 May, Chaitén produced three high ash plumes that drifted downwind across neighboring $\mathrm{Ar}$ gentina (Fig. 12b). Heavy ashfalls from these plumes not only blanketed settlements around Chaitén but also adversely affected extensive areas of neighboring Argentina downwind (e.g., Folch et al., 2008; Horwell et al., 2008; Martin et al., 2009; Watt et al., 2009). Explosive activity then subsided, and a new lava dome was observed within the crater on 21 May, even though dome extrusion probably began days earlier. As of this writing (August 2009), Chaitén remains active and the lava dome complex continues to grow, accompanied by small emissions of ash and steam (GVPb, 2009).

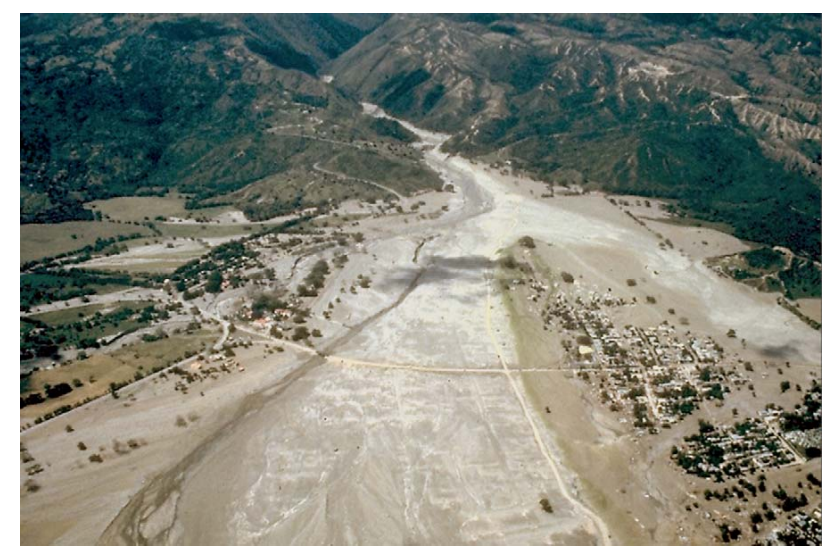

Fig. 10. Aerial oblique view of what remains of the city of Armero, Colombia, after it was devastated by destructive lahars generated by the 13 November 1985 eruption at Nevado del Ruiz (see text). These lahars swept down the steep valley of the Río Lagunillas (upper center of picture) (photograph by Richard Janda, USGS).

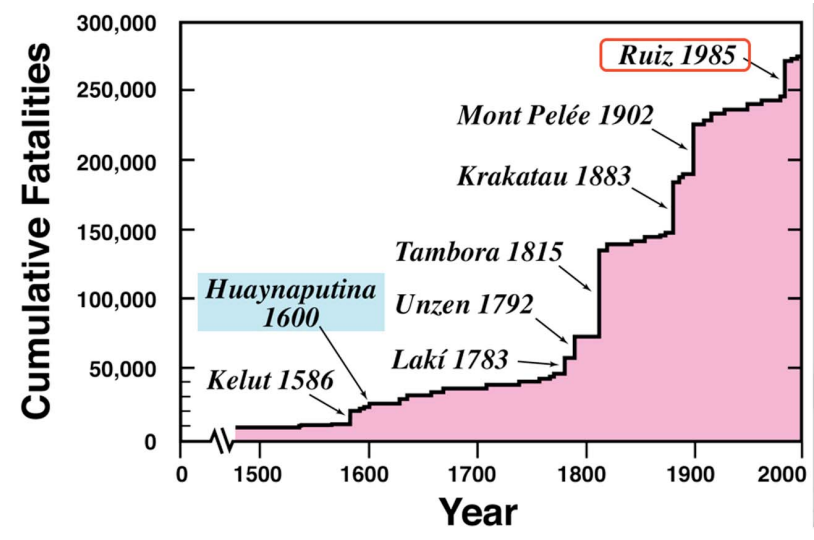

Fig. 11. Plot of the cumulative fatalities from volcanic eruptions worldwide during the period 1500-2000. Some of the worst historical volcanic disasters are identified; note the relatively small number fatalities for the huge 1600 Huaynaputina eruption compared with that for the much smaller eruption 1985 Ruiz eruption (see text) (data sources: Tilling, 1989; Simkin and Siebert, 1994; Tanguy et al., 1998).

Because of its location in a sparsely populated area ( $\sim 1200 \mathrm{~km}$ south of Santiago) and of its long quiescence, Chaitén was not considered a high volcanic threat and, hence, not monitored before 2008 (Lara et al., 2006). The volcano is now well monitored by instrumental networks established by SERNAGEOMIN with assistance of USGS-VDAP personnel. While the Chaitén eruption caused substantial socio-economic loss ( $\sim$ US $\$ 50$ millions estimated) in Chile and Argentina, disruption of local and international air traffic, and personal hardship for the evacuees, only one death occurred (of an elderly person stricken during the evacuations). This fortunate outcome is remarkable given the lack 


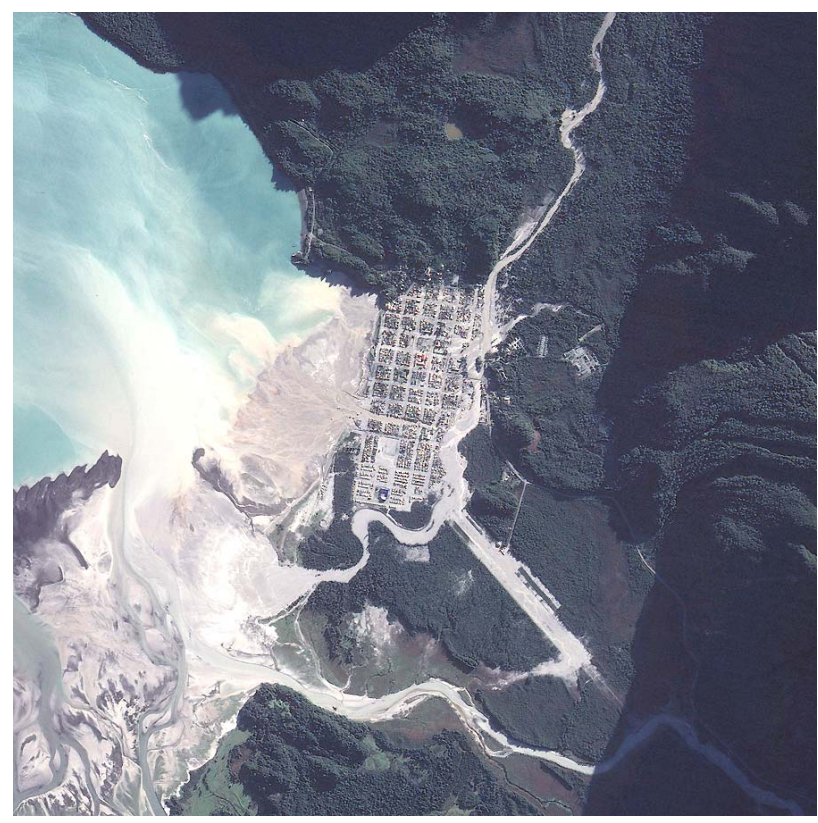

Fig. 12a. Satellite view showing the inundation of the town of Chaitén by lahars and floods as well as the suspended sediment offshore (Lara, 2009, Fig. 4a, image courtesy of NASA http:// earthobservatory.nasa.gov).

of pre-eruption volcano monitoring, thereby allowing very little time for scientists and officials to warn the populations at risk. The successful response to the Chaitén eruption represents another noteworthy example of the progress being made in volcano-risk reduction in the Andean region.

Of volcanological significance, the Chaitén eruption has involved the most voluminous expulsion of rhyolite magma from any volcano since the 1912 eruption of Novarupta (Alaska, USA). Moreover, this eruption is the first VEI 5 event in the 21 st century.

\section{How to reduce risk from Andean volcanoes?}

With passage of time, risks posed by eruptions of Andean volcanoes inevitably will increase - a situation that applies to any volcanic region. This increase in risk likely will not be caused by any possible escalation in the eruptive vigor of the world's volcanoes. The number of volcanoes active per year in the world has varied little over centuries, averaging between 50 and 70 in any given year (Simkin and Siebert, 1994). Heightened risk will result simply because of demographic and societal pressures: 1) exponential growth in world population in the 21 st century; 2 ) continued increase in air traffic (passenger and cargo); and 3) expansion of socioeconomic and agricultural development into more hazardous volcanic regions (Tilling, 2008a, Fig. 1). So then, how to reduce volcano risk in the Andean or any other volcanic region?

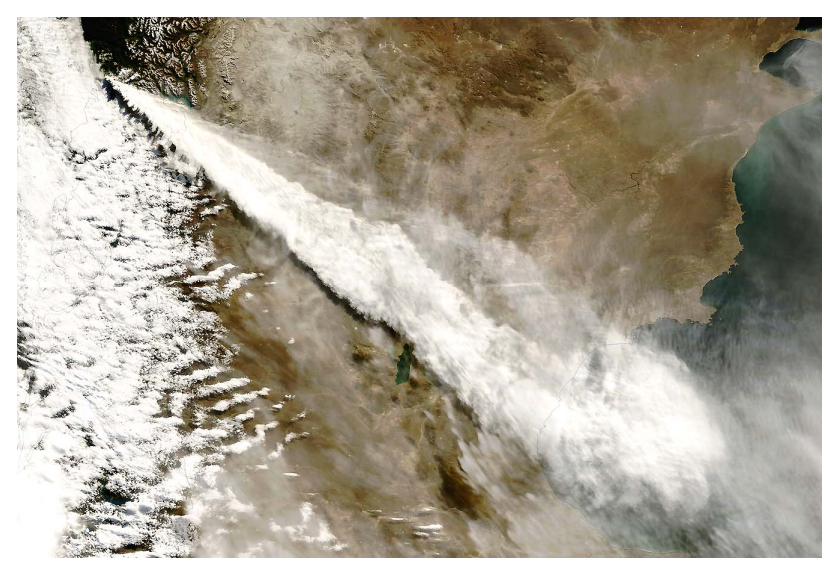

Fig. 12b. Satellite view of the first ashcloud from the eruption of Chaitén Volcano, southern Chile, drifting downwind across Argentina and dissipating over the Atlantic Ocean (MODIS/NASA image, 3 May 2008).

The basic strategy needed to reduce volcano risk in the Andean region is straightforward and consists of the following components, the specifics of which likely may vary from country to country, reflecting differences in socio-economic, political, and cultural factors:

- The conduct of basic studies (geologic, geochronologic, geophysical, etc.) of many more active and potentially active Andean volcanoes. Such studies are essential to reconstruct any given volcano's eruptive history - which in turn is essential for determining eruption recurrence intervals, long-term forecasts of possible future activity, including eruption style and size. At present, only a small number of Andean volcanoes have been studied adequately (Stern, 2004).

- Preparation of volcano-hazards assessments and hazards and risk maps. An important step in this regard was the recent completion of a modern volcanic-hazards map for El Misti Volcano in Peru (Mariño et al., 2007). The reactivation of this volcano would pose a major threat to the city of Arequipa, the second largest city in Peru ( $\sim$ one million population).

- Initiation or expansion/modernization of volcanomonitoring studies of high-risk volcanoes in the Andes. In this regard, the notoriety of 1985 Ruiz eruption, together with subsequent hazardous Andean eruptions has notably accelerated volcano-monitoring studies. As emphasized by Tilling (2008a, p. 4), “... data from volcano monitoring constitute the only scientific basis for shortterm forecasts (years to days) of a future eruption."

- Integral in developing any effective national program of volcano monitoring is the systematic evaluation of the 
level of threat posed by each of the country's volcanoes ("relative threat rankings") and the level of monitoring capabilities needed at each volcano. Recently, the US Geological Survey (USGS) undertook such an evaluation effort (Ewert et al., 2005) and proposed a "National Volcanic Early Warning System" (NVEWS) to adjust for the difference between current monitoring level and the required monitoring at each volcano (the so-called "gap analysis"). To date, the US has yet to establish the proposed NVEWS pending the availability of financial resources. However, the government of Chile, in response to the Chaitén eruption and continuing volcanic crisis, already has begun to implement a new national volcano-monitoring system (Red Nacional de Vigilancia Volcánica) similar to the NVEWS (Ewert et al., 2008; Carn et al., 2009).

- The development and practice of effective communications among scientists, emergency managers, news media, and the populace at risk are absolutely essential. This can be accomplished through regularly scheduled meetings between civil authorities and business leaders with emergency-response responsibilities together with scientists monitoring the local volcanoes. Indeed, without such effective communications, the scientific knowledge and monitoring data gained in the other three components of mitigation strategy are of little or no use in responding to a volcanic crisis. Reduction of volcano risk is predominantly achieved by governmental actions, regardless of the quantity and quality of scientific/technical data.

\section{Concluding remarks}

The disastrous outcome of the 1985 Ruiz eruption provided a sobering lesson for the global volcanological community: scientists, emergency managers, and the affected public must be better prepared to respond to the next volcanic crisis, wherever it may strike. In direct response to the Ruiz tragedy, in 1986 the U.S. Geological Survey (USGS) implemented the Volcanic Disaster Assistance Program (VDAP). The program, which is jointly funded by the USGS and the Agency for International Development's Office of Foreign Disaster Assistance (OFDA), involves the deployment of a rapid-response "mobile volcano observatory" (Murray et al., 1996) in assisting scientists in foreign countries in responding to volcanic crises. As one example of many, in early 1991, a quickly dispatched VDAP-USGS team, working with scientists of the Philippine Institute of Volcanology and Seismology (PHIVOLCS), contributed to the successful response to the climactic eruption of Mount Pinatubo on 15 June, the largest in the world since the 1912 Novarupta eruption. Acting on the forecast and recommendations of the PHIVOLCS-USGS scientists, authorities ordered timely evacuations, saving many thousands of lives and greatly reducing economic loss (Ewert et al., 1997). Other examples of recent VDAP responses include: Rabaul (Papua New Guinea) in 1994; Popocatépetl (Mexico), 1994-present; Guagua Pichincha and Tungurahua (Ecuador), 1999-present; Nevado del Huila (Colombia), 2007-present; and Chaitén (Chile), 2008-present.

Through the mid-1990s, efforts of the VDAP mostly consisted of the deployment of "mobile volcano observatories" and rapid-response teams. However, over the past decade, the program has evolved and become increasingly more concerned with pre-eruption infrastructure development and capacity building among the host-country institutions (many in the Andean countries) responsible for monitoring studies. As a consequence, the working philosophy of the VDAP now places higher priority on enhancing pre-crisis institutional capability - integrating basic geoscience studies, volcanomonitoring networks, information technology, hazards communications, etc. - rather than solely relying on rapid response when a crisis strikes. Currently, the VDAP allocates much more resources (monetary and personnel) to efforts in infrastructure building and technical training than to crisis responses (Jeffrey Marso, USGS-VDAP, written communication, July 2009).

The approach of involving VDAP-style mutual scientific assistance clearly has proven useful in reducing volcano risk. However, such an approach is hardly a panacea and must be considered an interim, stopgap solution. The optimum approach is for a country to develop self-sufficiency in volcanologic studies, preparation of hazards assessments and hazards-zonation maps, and a national volcano-monitoring capability matched to the relative threats posed by its active and potentially active volcanoes. From the preceding discussion, we have seen that the frequency and size of Andean eruptions are comparable to those of the more active regions elsewhere in the world. Accordingly, the two major volcanic disasters in the Andean region - Huaynaputina in 1600 and Ruiz in 1985 - should prompt the scientists and officials to maintain the momentum to attain self-sufficiency in volcanologic and volcano-monitoring studies that was spurred by the Ruiz tragedy. Given the population growth and economic development in Peru and other Andean countries in recent centuries, an Andean eruption comparable to the 1600 Huaynaputina eruption would likely have catastrophic consequences. Even the relatively small 1985 Ruiz eruption provides a painful reminder that eruptions need not be large to produce disastrous consequences, if mitigative responses are not taken in time. We should also not forget the harsh lesson from the deadly eruption in 1982 of a non-Andean volcano: El Chichón Volcano in southeastern Mexico. This eruption, which killed 2000 people and caused the worst volcanic disaster in Mexico's recorded history, came as a "surprise" to scientists and officials alike, because early warning signals of the precursory volcanic unrest went unheeded (Tilling, 2009). Had adequate volcano-monitoring data been available before 1982, and properly interpreted in consultation 
with knowledgeable specialists in Mexico and elsewhere, this eruption would not have been a surprise.

Following the 1985 Ruiz catastrophe, much progress has been achieved in volcanologic studies and volcanomonitoring networks for the Andean volcanoes (e.g., Kumagai et al., 2007), as the recent successful responses to the recent volcanic crises at Nevado del Huila and Chaitén amply attest. Yet, as noted by Stern (2004), at present fewer than 25 of the $\sim 200$ Holocene (potentially active?) Andean volcanoes are continuously monitored. Adequate monitoring of more Andean volcanoes will reduce the chances of surprise eruptions, thereby giving sufficient advance notice for scientists and emergency managers to better plan responses to future volcanic crises.

Acknowledgements. Special thanks go to the Organizing Committee for inviting me to participate in the Fourth Alexander von Humboldt Conference and to deliver a keynote presentation. Useful critical reviews of an earlier version of this paper by David Hill and Jeff Marso (both of the USGS Volcano Hazards Team), Felipe Aguilera (Universidad de Atacama, Chile), and an anonymous reviewer are very much appreciated. This paper draws heavily from the important work of Tom Simkin (whose untimely death occurred on 12 June 2009) and his associates at the Smithsonian Institution, Washington, DC, in building and maintaining the database for Holocene volcanoes of the world (see Global Volcanism Program at http://www.volcano.si.edu/).

Edited by: P. Fabian

Reviewed by: F. Aguilera, D. Hill, J. Marso and another anonymous referee

\section{References}

Adams, N. K., De Silva, S. L., Self, S., Salas, G., Schubring, S., Permenter, J. L., and Arbesman, K.: The physical volcanology of the 1600 eruption of Huaynaputina, southern Peru, B. Volcanol., 62, 493-518, 2001.

Allmendinger, R. W., Jordan, T. E., Kay, S. M., and Isacks, B. L.: The evolution of the Altiplano-Puna plateau of the central Andes, Annu. Rev. Earth Planet. Sci., 25, 139-174, 1997.

Agudelo, A. and Calvache, M.: Volcano emergency management at Nevado del Huila, Colombia [Abstract], Abstracts Volume, Cities on Volcanoes 5, 19-23 November 2007, Shimabara, Japan, 115-116, 2007.

Bitschene, P. R.: Environmental impact and hazard assessment of the August 1991 eruption of Mt. Hudson (Patagonian Andes), in: The August 1991 eruption of the Hudson Volcano (Patagonian Andes): A thousand days after, edited by: Bitschene, P. R. and Mendia, J., Cuvillier Verlag, Göttingen, Germany, 2-15, 1995.

Blong, R. J.: Volcanic Hazards: A Sourcebook on the Effects of Eruptions, Academic Press, Sydney and London, 424 pp., 1984.

Briffa, K., Jones, P. D., Schweingruber, F. H., and Osborn, T. J.: Influence of volcanic eruptions on Northern Hemisphere summer temperature over the past 600 years, Nature, 393, 450-455, 1998.

Calvache, M.: Colombia experiences of managing volcanic crisis, Galeras and Nevado del Huila eruptions [Abstract], Ab- stracts Volume, Cities on Volcanoes 5, 19-23 November 2007, Shimabara, Japan, 153-154, 2007.

Cardona, C., Calvache, M., Pulgarin, B., Agudelo, Ad., Santacoloma, C., Lockhart, A., White, R., and Marso, J.: Seismic Signals Associated to Phreatic Eruptions of the Nevado del Huila Volcano (Colombia), February and April 2007 [Abstract], Abstracts Volume, Cities on Volcanoes 5, 19-23 November 2007, Shimabara, Japan, 73-74, 2007.

Carn, S. A., Pallister, J. S., Lara, L., Ewert, J. W., Prata, A. J., Thomas, R. J., and Villarosa, G.: The unexpected awakening of Chaitén Volcano, Chile, Eos, Transactions American Geophysical Union, 90(24), 205-212, 2009.

Chouet, B.: Volcano seismology, Pure Appl. Geophys., 160(3-4), 739-788, 2004.

De Silva, S. L. and Zielinski, G. A.: Global influence of the AD1600 eruption of Huaynaputina, Peru, Nature, 393, 455-458, 1998.

Dzurisin, D. (Ed.): Volcano deformation: Geodetic Monitoring Techniques: Springer-Praxis, Berlin, Germany, and Chichester, UK, 441 pp., 2006.

Ewert, J. W., Miller, C. D., Hendley, J. W., and Stauffer, P. H.: Mobile Response Team saves lives in volcanic crises, US Geological Survey Fact Sheet, 064-97, 2 pp., 1997.

Ewert, J. W., Guffanti, M., and Murray, T. L.: An assessment of volcanic threat and monitoring capabilities in the United States: Framework for a National Volcano Early Warning System (NVEWS), US Geological Survey Open-File Report 2005-1164, 62 pp., 2005.

Ewert, J. W., Lara, L. E., and Moreno, H.: The 2008 Eruption of Chaitén Volcano, Chile and National Volcano-Monitoring Programs in the US and Chile [Abstract], Eos, Transactions of the American Geophysical Union, 89(53), Fall Meeting Supplement, Abstract V43D-2177, 2008.

Folch, A., Jorba, O., and Viramonte, J.: Volcanic ash forecast application to the May 2008 Chaitn eruption, Nat. Hazards Earth Syst. Sci., 8, 927-940, 2008, http://www.nat-hazards-earth-syst-sci.net/8/927/2008/.

Froger, J. L., Remy, D, Bonvalot, S, and Legrand, D.: Two scales of inflation at Lastarria- Cordon del Azufre volcanic complex, central Andes, revealed from ASAR-ENVISAT interferometric data, Earth Planet. Sci. Lett., 255, 148-163, 2007.

Gelcich, S., Spooner, E. T. C., and Davis, D. W.: Tracking the basement of early Andean magmatism: U-Pb ages of zircon xenocrysts of the La Negra Formation in the Coastal Cordillera near Chañaral $\left(\sim 26^{\circ} \mathrm{S}\right)$, Northern Chile (Extended Abstract), Abstracts Volume, 6th International Symposium on Andean Geodynamics (ISAG 2005, Barcelona), 308-311, 2005.

González-Ferrán, O.: Volcanoes de Chile: Instituto Geográfico Militar, Santiago, Chile, 639 pp., 1995.

GVPa: SI/USGS Weekly Reports Volcanic Activity Reports, Nevado del Huila: Global Volcanism Program website, online available at: http://www.volcano.si.edu/reports/usgs/\#huila, last access: August 2009.

GVPb: SI/USGS Weekly Reports Volcanic Activity Reports, Chaitén: Global Volcanism Program website, online available at: http://www.volcano.si.edu/reports/usgs/\{\#\}chaiten, last access: August 2009.

GVPc, 2009, Large Holocene eruptions: Global Volcanism Program website, , online available at: http://www.volcano.si.edu/ world/largeeruptions.cfm, last access: August 2009. 
Hall, M. and Mothes, P.: The rhyolitic-andesitic eruptive history of Cotopaxi volcano, Ecuador, . Volcanol., 70, 675-702, 2008.

Hall, M. L., Samaniego, P., Le Pennec, J. L., and Johnson, J. B.: Ecuadorian Andes volcanism: A review of Late Pliocene to present activity, J. Volcanol. Geoth. Res., 176, 1-6, 2008.

Hildreth, W., and Drake, R. E.: Volcán Quizapu, Chilean Andes, 1992, B. Volcanol., 54, 93-125, 1992.

Hill, D. P.: Unrest in Long Valley Caldera, California, 1978-2004, Geological Society of London, Special Publications, 269, 1-24, 2006.

Horwell, C. J., Michnowicz, S., Le Blond, J.: Report on the mineralogical and geochemical characterisation of Chaitén ash for the assessment of respiratory health hazard: University of DurhamIVHHN-Natural Environmental Research Council (unpublished data), 36 pp., 2008.

Kumagai, H., Yepes, H., Vaca, M., Caceres, V., Nagai, T., Yokoe, K., Imai, T., Miyakawa, K., Yamashita, T., Arrais, S., Vasconez, F., Pinajota, E., Cisneros, C., Ramos, C., Paredes, M., Gomezjurado, L., Garcia-Aristizabal, A., Molina, I., Ramon, P., Segovia, M., Palacios, P., Troncoso, L., Alvarado, A., Aguilar, J., Pozo, J., Enriquez, W., Mothes, P., Hall, M., Inoue, I., Nakano, M., and Inoue, H.: Enhancing Volcano-Monitoring Capabilities in Ecuador, Eos, 88(23), 245-252, 2007.

Lara, L. E., Clavero, J., Hinojosa, M., Huerta, S., Wall, R., and Moreno, H.: NVEWS-CHILE: Sistema de Clasificación semicuantitativa de la vulnerabilidad volcánica, in Congreso Geológico Chileno (Antofagasta, Chile), 11(2), 487-490, 2006.

Lara, L. E.: The 2008 eruption of Chaitn Volcano, Chile: A preliminary report, Andean Geology, 36(1), 125-129, 2009.

Larsson, W.: Vulkanische Asche vom Ausbruch des chilenischen Vulkans Quizapu (1932) in Argentina gseammelt, Bulletin Geological Institution of Uppsala, 26, 27-52, 1937.

Mariño, J., Rivera, M., Cacya, L., Thouret, J.-C., Macedo, L., Salas, G., Siebe, C., Tilling, R. I., Sheridan, M., Chávez, A., and Zuñiga, S.: Mapa de Peligros del Volcán Misti: Instituto Geológico Minero y Metalúrgico, Lima, Perú, (Main map, scale 1:50000; 3 inset maps at variable scales), 2007.

Martin, R. S., Watt, S. F. L., Pyle, D. M., Mather, T. A., and Matthews, N. E.: Environmental effects of ashfall in Argentina from the 2008 Chaitén volcanic eruption, J. Volcanol. Geoth. Res., 184, 462-472, 2009.

Mason, B. G., Pyle, D. M., and Oppenheimer, C.: The size and frequency of the largest explosive eruptions on Earth, B. Volcanol., 66(8), 735-748, 2004.

Méndez Fajury, R. A.: Catálogo de volcanes activos de Colombia, Boletín Geológico del Instituto Colombiano de Geología y Minería, 30, 1-75, 1989.

Moreno, H. and Lara, L. E.: Peligros volcánicos potenciales del volcán Chaitén (erupción de mayo 2008), Región de los Lagos. Servicio Nacional de Geología y Minería, 1 mapa escala 1:500000 (unpublished data), 2008.

Mothes, P., Hall, M. L., Andrade, D., Samaniego, P., Pierson, T. C., Ruiz, A. G., and Yepes, H.: Character, stratigraphy and magnitude of historical lahars of Cotopaxi Volcano (Ecuador), Acta Vulcanol., 16(1/2), 85-108, 2004.

Murray, T. L., Ewert, J. W., Lockhart, A. B., and LaHusen, R. G.: The Integrated Mobile Volcano-Monitoring System used by the Volcano Disaster Assistance Program (VDAP), in: Monitoring and mitigation of volcano hazards, edited by: Scarpa, R. and
Tilling, R. I., : Springer-Verlag, Heidelberg, Germany, 315-362, 1996.

Naranjo, J., Moreno, H., and Banks, N. G.: La erupción del Volcán Hudson en 1991 (46 S), XI Región, Aisén, Chile, Servicio Nacional Geológico Mineralógico Boletín, 44, 50 pp., 1993.

Naranjo, J. A. and Stern, C. R.: Holocene tephrochronology of the southernmost part $\left(42^{\circ} 30^{\prime}-45^{\circ} \mathrm{S}\right)$ of the Andean Southern Volcanic Zone: Revista Geológica de Chile, 31(2), 225-240, 2004.

Newhall, C. G. and Self, S.: The volcanic explosivity index (VEI): An estimate of explosive magnitude for historical volcanism, J. Geophys. Res., 87, 1231-1238, 1982.

Newhall, C. G. and Dzurisin, D.: Historical Unrest at Large Calderas of the World, US Geological Survey Bulletin, 1855(2), 1102 pp., 1988.

Newhall, C. G. and Punongbayan, R. S. (Eds.): Fire and Mud: Eruptions and Lahars of Mount Pinatubo, Philippines: Philippine Institute of Volcanology and Seismology, Quezon City, and University of Washington Press, Seattle, 1126 pp., 2006.

Oliveros, V., Féraud, G., Aguirre, L., Fornari, M., and Morata, D.: The Early Andean Magmatic Province (EAMP): 40Ar/39Ar dating on Mesozoic volcanic and plutonic rocks from the Coastal Cordillera, northern Chile, J. Volcanol. Geoth. Res., 157(4), 311330, 2006.

Pulgarin, B., Cardona, C., Calvache, M., Lockhart, A., and White, R.: Huila Lahars Caused by Rapid, Voluminous Water Expulsion [Abstract], Abstracts Volume, Cities on Volcanoes 5, 19-23 November 2007, Shimabara, Japan, p. 115, 2007.

Ruch, J., Anderssohn, J., Walter, T. R., and Motagh, M.: Calderascale inflation of the Lazufre volcanic area, South America: Evidence from InSAR, J. Volcanol. Geoth. Res.,137, 337-344, 2008.

Scarpa, R. and Tilling, R. I. (Eds.): Monitoring and mitigation of volcano hazards: Springer-Verlag, Heidelberg, Germany, 841 pp., 1996.

Scasso, R. A., Corbella, H., and Tiberi, P.: Sedimentological analysis of the tephra from the 12-15 August 1991 eruption of Hudson volcano, B. Volcanol., 56, 121-132, 1994.

Scheuber, E. and Reutter, K. J.: Magmatic arc tectonics in the Central Andes between $21^{\circ}$ and $25^{\circ} \mathrm{S}$ : Tectonophysics, 205, 127 140, 1992.

Simkin, T. and Siebert, L.: Volcanoes of the World - A Regional Directory, Gazetteer, and Chronology of Volcanism during the last 10000 years, Tuscon, Geoscience Press, Inc., 349 pp., 1994.

Simkin, T., Tilling, R. I., Vogt, P. R., Kirby, S., Kimberly, P., and Stewart, D. B.: This Dynamic Planet: A World Map of Volcanoes, Earthquakes, Impact Craters, and Plate Tectonics. Third Edition, US Geological Survey, Reston, Virginia (scale 1: 30000000 at equator), 2006

Stern, C. R.: Active Andean volcanism: Its geologic and tectonic setting, Revista Geológica de Chile, 31(2), 161-206, 2004.

Tanguy, J.-C., Ribière, C., Scarth, A., and Tjetjep, W. S.: Victims from volcanic eruptions: A revised database, B. Volcanol., 60(2), 137-144, 1998.

Thouret, J.-C., Davila, J., and Eissen, J.-P.: Largest explosive eruption in historical times in the Andes at Huaynaputina volcano, AD 1600, southern Peru, Geology, 27, 435-438, 1999.

Thouret, J.-C., Juvigne, E., Gourgaud, A., Boivin, P., and Dávila, J.: Reconstruction of the AD 1600 Huaynaputina eruption based on the correlation of geologic evidence with early Spanish chronicles, J. Volcanol. Geoth. Res., 115, 529-570, 2002. 
Tilling, R. I.: Volcanic hazards and their mitigation: Progress and problems, Rev. Geophys., 27(2), 237-269, 1989.

Tilling, R. I.: Volcano hazards, in: Volcanoes and the Environment, edited by: Martí, J. and Ernst, G., Cambridge University Press, Cambridge, UK, Chap. 2, 56-89, 2005.

Tilling, R. I.: The critical role of volcano monitoring in risk reduction, Adv. Geosci., 14, 3-11, 2008a, http://www.adv-geosci.net/14/3/2008/.

Tilling, R. I.: Volcanism and associated hazards: The Andean perspective [Abstract], Program and Abstracts, International Conference on The Andes: Challenge for Geosciences, 24-28 November 2008, Santiago, Chile, p. 48, 2008b.

Tilling, R. I.: El Chichón's "surprise” eruption in 1982: Lessons for reducing volcano risk, Geofísica Internacional, 48(1), 3-19, 2009.

TOMS-VEG: TOMS Volcanic Emissions Group: University of Maryland/Baltimore County (UMBC), Maryland, USA, online available at: http://toms.umbc.edu, 2008.

Troise, C., De Natale, G., Pinque, F., Obrizzo, F., De Martino, P., Tammaro, U., and Boschi, E.: Renewed ground uplift at Campi Flegrei caldera (Italy): New insight on magmatic processes and forecast, Geophys. Res. Lett., 34, L03301, doi:10.1029/2006GL28545, 2007.

Verosub, K. L. and Lippman, J.: Global Impacts of the 1600 Eruption of Peru's Huaynaputina Volcano, Eos Transactions, American Geophysical Union, 89(15), p. 141, doi:10.1029/2008EO150001, 2008.
Voight, B.: The 1985 Nevado del Ruiz volcano catastrophe: anatomy and retrospection, J. Volcanol. Geoth. Res., 42, 151188, 1994.

Voight, B.: The management of volcano emergencies, in: Monitoring and mitigation of volcano hazards, edited by: Scarpa, R. and Tilling, R. I., Springer Verlag, Heidelberg, Germany, 719-769, 1996.

Waite, G. P. and Smith, R. B.: Seismic evidence for fluid migration accompanying subsidence of the Yellowstone caldera, J. Geophys. Res., 107, 2177-2192, 2002.

Watt, S. F. L., Pyle, D. M., Mather, T. A., Martin, R. S., and Matthews, N. E.: Fallout and distribution of volcanic ash over Argentina following the May 2008 explosive eruption of Chaitén, Chile, J. Geophys. Res., 114, B04207, doi:10.1029/2008JB006219, 2009.

Wicks, C., Thatcher, W., Dzurisin, D., and Svarc, J.: Uplift, thermal unrest, and magma intrusion at Yellowstone Caldera, Nature, 440, 72-75, 2006.

Williams, S. (Ed.): Nevado del Ruiz, Colombia, J. Volcanol. Geoth. Res., 41, 379 pp. [collection of 18 papers], 1990a.

Williams, S. (Ed.): Nevado del Ruiz, Colombia, J. Volcanol. Geoth. Res., 42, 224 pp. [collection of 13 papers], 1990b. 